\title{
Experiential Marketing, Product Diversity, and Location to the Decision to Make a Reservation at Al\&Co Coffee Shop
}

\author{
*Ayuningtyas Yuli Hapsari ${ }^{1}$, Kurniawan ${ }^{2}$, Tezza Adriansyah Anwar ${ }^{3}$, \\ Koesmawan $^{4}$ \\ ${ }^{1}$ Faculty of Economic and Business, Universitas Widyatama, Bandung, West Java, Indonesia \\ ${ }^{2}$ Faculty of Economic, Nusaputra University, Sukabumi, West Java, Indonesia \\ ${ }^{3}$ Faculty of Medicine, Universitas Jenderal Achmad Yani, Cimahi, West Java, Indonesia \\ ${ }^{4}$ Institut Teknologi dan Bisnis Ahmad Dahlan, Jakarta, Indonesia \\ *Corresponding author. E-mail: ayuningtyas.yuli@widyatama.ac.id
}

\begin{abstract}
The emergence of coffee shops occurs because of changes in people's habits and lifestyles, initially drinking coffee was only done at home, becoming in coffee shops. This opportunity is used by business people who try their luck to open a business in the coffee shop field. This study intends to determine the relationship between experience marketing, product diversity, and location and the influence of experiential marketing, product diversity, and location on the choice to make a reservation at Al\&Co coffee shops. The descriptive verification approach is used in this study. The population of Bandung City was chosen as a sample. The surveys were dispersed uniformly among the five areas utilizing logistics and hypothesis testing. According to the research, experiential marketing and product variety have a partial or simultaneous effect on making a reservation at Al\&Co coffee shop.
\end{abstract}

Keywords: Experiential Marketing, Product Diversity, Location, Consumer Decision.

\section{INTRODUCTION}

Indonesia is one of the countries producing coffee commodities with the best quality that is no less competitive with other countries, so most of the population likes the drink. As a result of the changing times, it impacts changes in habits and lifestyles, which used to be the habit of drinking coffee only at home, experiencing a shift to modern coffee outlets called coffee shops. At this time, a coffee shop not only relies on quality coffee beans but also offers a modern and 'contemporary' interior design so that people, especially young people, come to visit to make purchases. With the rapid growth of coffee shops in Indonesia, many business people are trying to work in the coffee shop business. To face business competition, innovations are needed by business people to develop their coffee shops amid fairly tight competition. There needs to be differentiation or differentiation so that the coffee shop business can continue to survive.
The emergence of coffee shops occurs in big cities in Indonesia, one of which is in Cimahi City, West Java. One of the coffee shops located in Cimahi City, namely Al\&Co, exploited this opportunity. Al\&Co is a coffee shop located in Cimahi City, West Java. Al\&Co is a coffee shop with the concept of 'feels like coffee at home because the place is joined to the house of the Al\&Co coffee shop owner. The coffee products offered have quality coffee beans that are of high quality and are rarely found in other coffee shops. The most striking difference between Al\&Co coffee shop and other coffee shops is that consumers must make a reservation or appointment first via direct message on Al\&Co's Instagram social media account before visiting because the place can be said to be small. Al\&Co only provides three meeting sessions, namely morning, afternoon, and evening a maximum 
of 3 hours for each session, and in each session, there is only a maximum of 5 consumers.

Based on consumers' experiences who have made visits, they find it difficult to make reservations or appointments because there is no clear information provided by Al\&Co when consumers get the opportunity to visit. This is because Al\&Co does not provide certainty from afar, but suddenly so that sometimes consumers complain about it.

Coffee. Al\&Co Coffee Shop only provides beverage products, but consumers can order food products. If they want to order food products, consumers must place an order before coming to the place. The beverage products offered by the Al\&Co coffee shop are not as many as other coffee shops because the Al\&Co coffee shop does not provide noncoffee drinks or blended drinks but only provides coffee drink products, and the beverage products provided are less varied so that consumers do not have various choices for ordering drinks. The atmosphere presented in the Al\&Co coffee shop is quite comfortable because it is home-themed and its interior can attract the attention of consumers to make reservations. The location of the Al\&Co coffee shop is located on JL. Central No. 38, Cibabat, Kec. North Cimahi, Cimahi City, West Java. As for the Al\&Co coffee shop's location, it is located in a residential complex. Therefore, Al\&Co coffee shop has limited vehicle access, especially for consumers who use fourwheeled vehicles. Locations that are less affordable are the drawbacks of Al\&Co coffee shops, consumers who will visit are advised to use two-wheeled vehicles or public transportation considering the limited access to parking their vehicles.

Consumer dissatisfaction with the experience in making reservations or appointments, the lack of variety of products offered, and the inaccessibility of locations owned by Al\&Co coffee shops do not affect consumers' desire to make reservations or appointments. The consumer desire to make reservations or appointments at $\mathrm{Al} \& \mathrm{Co}$ coffee shops is still strong, considering that many have made reservations or appointments but have not had the opportunity to visit the coffee shop. The researchers performed a pre-survey of 30 consumers to bolster the data on the choice to make a reservation at the Al\&Co coffee shop. The following are the findings of a presurvey conducted prior to making a reservation at Al\&Co coffee shop:
Table 1. Pre-Survey Result-Decision for Reservation

\begin{tabular}{|c|c|c|c|}
\hline No. & Statement & Yes & No \\
\hline 1. & $\begin{array}{l}\text { I have made a reservation or an } \\
\text { appointment at Al\&Co. coffee } \\
\text { shop }\end{array}$ & $90 \%$ & $10 \%$ \\
\hline 2. & $\begin{array}{l}\text { I am interested in making a } \\
\text { reservation or appointment at the } \\
\text { Al\&Co coffee shop because of the } \\
\text { reviews given by consumers who } \\
\text { have visited }\end{array}$ & $70 \%$ & $30 \%$ \\
\hline 3. & $\begin{array}{l}\text { I am interested in making a } \\
\text { reservation or appointment at the } \\
\text { Al\&Co coffee shop because of the } \\
\text { beverage products they offer }\end{array}$ & $57 \%$ & $43 \%$ \\
\hline 4. & $\begin{array}{l}\text { I am interested in making a } \\
\text { reservation or appointment at the } \\
\text { AI\&Co coffee shop because of the } \\
\text { interior provided interior }\end{array}$ & $63 \%$ & $37 \%$ \\
\hline
\end{tabular}

Shop Al\&Co. According to the results of the presurvey in Table 1, the majority of consumers have booked reservations or appointments at Al\&Co coffee shops after reading the feedback left by previous visitors. Additionally, most customers are interested in booking reservations or appointments at $\mathrm{Al} \& \mathrm{Co}$ coffee shops due to available beverage items. Most consumers are interested in booking reservations or appointments at Al\&Co coffee shops due to the interior design given. This means that, even though the consumer experience regarding the reservation or appointment method is less practical, the limitations of the products sold and the location is quite challenging to reach, the consumer's desire to make a reservation or an appointment at the Al\&Co coffee shop remains high so it can be concluded that consumers still want to visit the coffee shop.

\section{LITERATURE REVIEW}

\subsection{Experiential Marketing}

Experiential marketing is a person's memory or experience that can influence the desire to purchase the emotions generated [1]. According to Schmitt in Putri et al., Experiential marketing may be quantified along 
five dimensions: perceive, feel, think, act, and relate [2].

$\mathrm{H} 1$ : Experiential marketing influences the decision to make a reservation at Al\&Co Coffee Shop.

\subsection{Product Diversity}

Product diversity is a set of product or service variations provided and offered to consumers, including length, width, depth, consistency, and product quality [3]. According to Kotler, four dimensions measure product diversity, namely product brand variations, product completeness variations, product size variations, and product quality variations [4].

H2: Product Diversity influences the decision to make a reservation at Al\&Co Coffee Shop.

\subsection{Location}

Location is the physical structure of the business placement used by a coffee shop. The location used by the coffee shop is expected to have a strategic location that is easy to find, easy to reach, easy to see, and widely traversed and inhabited by target consumers who have the potential to buy products [5]. The dimensions of the location are divided into five, namely access, visibility, traffic, and parking [6].

H3: Location influences the decision to make a reservation at Al\&Co Coffee Shop.

\subsection{Decision to Make a reservation}

Purchasing decisions are a form of consumer behavior to obtain and determine the products and services needed, including purchasing decisions. In general, purchasing decisions are influenced by needs and habits [6].

H4: Experiential Marketing, Product Diversity dan Location influences the decision to make a reservation at Al\&Co Coffee Shop.

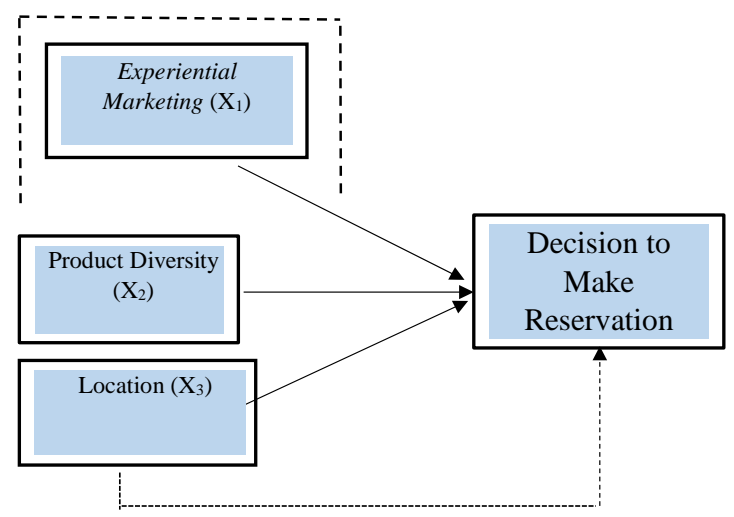

Figure 1. Research Model

\section{RESEARCH METHOD}

The descriptive-verificative approach was applied in this study. The descriptive method is used to describe, explain and describe the variables studied, while the verification method is used to test the hypothesis [7]. The population studied in this study is the Bandung City population, which is evenly dispersed throughout five regions: North Bandung, South Bandung, East Bandung, West Bandung, and Central Bandung. Due to the unknown population size in this study, the sample size was determined using the iteration approach to be as many as 120 Bandung City residents. According to Sitepu, iteration is consistent with the analytical methods employed for hypothesis testing [8].

\section{RESULT AND DISCUSSION}

\subsection{Regression Model Feasibility Test}

The standard assumption test (normality test) is not required in this study, but a feasibility test is required to test model fit. To determine the viability of the logistic regression model utilized in this study. The following are the outcomes of statistical tests conducted using SPSS 20:

Table 2. Test Level of Accuracy

\begin{tabular}{|c|c|c|c|c|c|}
\hline & & $\begin{array}{l}\text { Classi } \\
\text { Table }\end{array}$ & ificati & & \\
\hline & & & Predi & ed & \\
\hline Observ & red & & $\begin{array}{l}\text { The } \mathrm{c} \\
\text { to } \mathrm{M} \text { c } \\
\text { reser }\end{array}$ & $\begin{array}{l}\text { cision } \\
\text { e a } \\
\text { ttion }\end{array}$ & $\begin{array}{l}\text { Percentage } \\
\text { Correct }\end{array}$ \\
\hline & & & 1.00 & 2.00 & \\
\hline & Reservation & 1.00 & 0 & 14 & .0 \\
\hline$S_{t a n} 1$ & Decision & 2.00 & 0 & 101 & 100.0 \\
\hline 1 & $\begin{array}{l}\text { Overall } \\
\text { Percentage }\end{array}$ & & & & 87.8 \\
\hline $\begin{array}{l}\text { a. The } \\
.500\end{array}$ & cut value is & & & & \\
\hline
\end{tabular}

Source. Data Processing Result with SPSS ver 20.

According to Table 2, the degree of accuracy is 87.8. This is demonstrated by the Overall Percentage, which stands at 87.8 .

\subsection{Feasibility Test of Hosmer and Lemeshow Model}

Lemeshow and Hosmer the test is a goodness of fit, which determines whether or not the model generated is suitable. The following are the outcomes of the data processing: 
Table 3. Test Level of Accuracy Model Hosmer and Lemeshow

Hosmer and Lemeshow Test

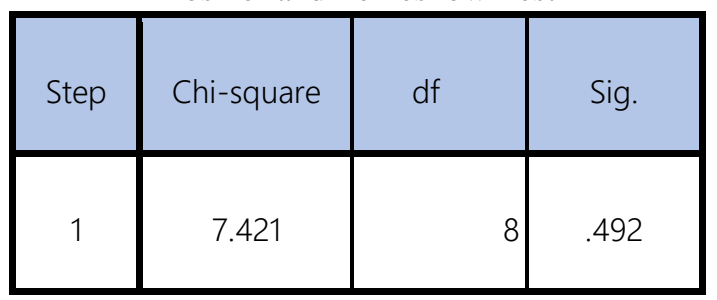

In table 3, Chi-Square is 0.492 , and a significant value $>0.05$ indicates that this model is fit.

\subsection{Nagelkerke R Square Test}

By examining the Cox and Snell's R Square values, the model evaluation test determines how much of the dependent variable can be explained by the independent variable. The output findings of Cox and Snell's R Square are analogous to those of linear regression's R-Square. The following are the outcomes of the data processing:
Table 4. Nagelkerke R Square Test Result

Model Summary

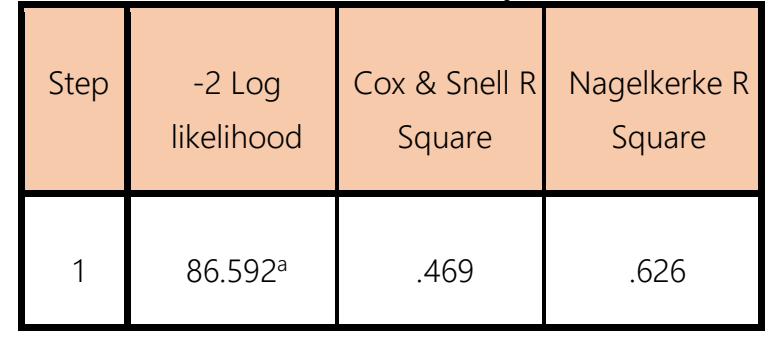

According to Table 4, the Cox \& Snell $\mathrm{R}$ Square value is 0.469 , indicating that experiential marketing characteristics, product diversity, and location contribute 46.9 percent to purchase choices. The Negelkerke R Square is 0.626 , indicating that 62.6 percent of the independent variance variable can be explained by the independent variable, while the remaining 37.4 percent is influenced by external variables, such as brand image, service quality, and social media promotion.

Table 5. Hypothesis Test

\begin{tabular}{|c|c|c|c|c|}
\hline Hypothesis Null & f-value & f-table & Result & Meaning \\
\hline $\begin{array}{l}\text { Experiental marketing, product variety, } \\
\text { location has no impact on decision }\end{array}$ & 45,787 & 2,69 & $\begin{array}{l}\mathrm{f}_{\text {value }}>\mathrm{f}_{\text {table }} \\
\mathrm{H}_{0} \text { accepted }\end{array}$ & $\begin{array}{l}\text { Experiential marketing, } \\
\text { product variety, location have } \\
\text { a significant impact on } \\
\text { decision }\end{array}$ \\
\hline Hypothesis Null & $\mathrm{t}$-value & t-table & Result & Meaning \\
\hline $\begin{array}{l}\text { Experiential marketing has no impact on } \\
\text { decision }\end{array}$ & 2,746 & 1.981 & $\begin{array}{r}t_{\text {value }}<t_{\text {table }} \\
H_{0} \text { accepted }\end{array}$ & $\begin{array}{l}\text { Experiential marketing has a } \\
\text { significant impact on decision }\end{array}$ \\
\hline $\begin{array}{l}\text { Product variety has no impact on } \\
\text { decision }\end{array}$ & 2,811 & 1.981 & $\begin{array}{l}t_{\text {value }}<t_{\text {table }} \\
H_{0} \text { accepted }\end{array}$ & $\begin{array}{l}\text { Product variety has a } \\
\text { significant impact on decision }\end{array}$ \\
\hline The location has no impact on decision & 2,198 & 1.981 & $\begin{array}{l}t_{\text {value }}<t_{\text {table }} \\
H_{0} \text { accepted }\end{array}$ & $\begin{array}{l}\text { Location has significant impact } \\
\text { on decision }\end{array}$ \\
\hline
\end{tabular}

According to the analysis's findings, experiential marketing, product diversity, and location, all had a 62.6 percent effect on the choice to make a reservation at Al\&Co coffee shop, while the remaining 37.4 percent was influenced by variables not included in this study. That is, the experiential marketing characteristics of sense, feel, think, act, and relate all contribute to the choice to make a reservation at Al\&Co coffee shop. Then other variables, namely product diversity, which has dimensions of product brand variations, product completeness variations, product size variations, and product quality variations, contribute to consumer decisions in making reservations as well as other independent variables, namely locations that have the dimensions of access, visibility, traffic, and the parking lot influences the decision to make a reservation made by consumers. 


\section{CONCLUSION AND SUGGESTION}

These three variables have a strong influence on consumer decisions. Experiential marketing, product diversity, and location significantly impact customer decision to make a reservation at $\mathrm{Al} \&$ Co coffee shop. Partially, each variable also has significant impact on customer decision to make a reservation at the $\mathrm{Al} \&$ Co coffee shop.

Confirming the visit schedule obtained by consumers far in the day can enhance the marketing experiential of consumers. Al \& Co Coffee shop can provide food or snacks ordered online or provide packages that include food and beverages. This needs to be done because there is no snack to accompany the coffee. Even if available, the number and variation are limited. The availability of parking spaces also needs to be improved as there is currently only parking for motorcycles. Providing alternative parking lots and informing consumers who bring cars can be an alternative solution in this regard. Another thing that can be done is to inform consumers about motorcycles or public vehicles. Further research can be done by looking at the variables of brand image, service quality, social media promotion.

\section{REFERENCES}

[1] Engel, J.F, Roger D., Blackwell and Paul W.M. 1995. Perilaku Konsumen. Dialih Bahasakan Oleh Farli Liwe. 2015. Edisi Enam. Jakarta: Binarupa Aksara.

[2] Putri, K.C., Rusminah dan Lalu M.F. 2020. Pengaruh Experiential Marketing Terhadap Minat Berkunjung Ulang Konsumen Mcdonald's Sriwijaya. Jurnal Ekonomi Pembangunan, Vol. 2, No. 1.

[3] Sitepu, N.S.K. 2015. Analisis Jalur (Path Analysis), Unit Pelayanan Statistika Jurusan Statistika. Bandung: FMIPA UNPAD.
[4] Sugiyono. 2017. Metode Penelitian Pendidikan Pendekatan Kuantitatif, Kualitatif dan R\&D. Bandung: Alfabeta.

[5] Sunyoto, D. 2015. Manajemen dan Pengembangan Sumber Daya Manusia. Yogyakarta: Center for Academic Publishing Service.

[6] Tantowi, A.I., dan Anton W.P. 2020. Pengaruh Store Atmosphere dan Experiential Marketing Terhadap Keputusan Pembelian di Kopi Daong Pancawati. Jurnal Ilmiah Manajemen Kesatuan, Vol. 8 No. 2.

[7] Tjiptono dan Gregorius C. 2016. Pemasaran Jasa (Prinsip, Penerapan, dan Penelitian). Yogyakarta: Andi.

[8] Utami, C.W. 2015. Manajemen Ritel. Jakarta: Salemba Empat. 